\title{
Horner's syndrome in Wegener's granulomatosis: report of four cases
}

\author{
Hiroshi Nishino, Frank A Rubino
}

\begin{abstract}
Four patients with active Wegener's granulomatosis had Horner's syndrome, which was the only neurological involvement in one. Two others had multiple mononeuropathy and one a multiple cranial neuropathy. Horner's syndrome occurred in the active stage and improved with treatment of Wegener's granulomatosis.
\end{abstract}

$(\mathfrak{F}$ Neurol Neurosurg Psychiatry 1993;56:897-899)

Horner's syndrome (oculosympathetic paresis) results from interruption of the sympathetic nerve supply to the pupil, eyelids, and facial sweat glands. ${ }^{12}$ The lesion may involve first order neurons descending from the hypothalamus to the ciliospinal centre in the upper thoracic cord; second order (preganglionic) neurons taking a course through the posterosuperior aspect of the chest and ascending in the neck along the carotid artery; or third order (postganglionic) neurons originating in the superior cervical ganglion to the face and to the orbit. ${ }^{2}$

Since the first description of Horner's syndrome in $1869,{ }^{3}$ it has been reported in association with various diseases, including cerebrovascular events in the hypothalamus or brainstem, carcinoma of the apex of the lung invading the lower brachial plexus, iatrogenic injury to the sympathetic chain in the neck, and cavernous sinus disease. ${ }^{2}$ In an analysis of 216 patients examined between 1936-58, Giles and Henderson ${ }^{4}$ found that the cause of the syndrome was neoplasia in $35.6 \%$ of patients, surgical procedures in $18.5 \%$, trauma in $13 \%$, other causes in $4.2 \%$,
Table Summary of clinical and laboratory findings

\begin{tabular}{|c|c|c|c|c|}
\hline & Case 1 & Case 2 & Case 3 & Case 4 \\
\hline $\begin{array}{l}\text { Nasal symptoms } \\
\text { ESR (mm/hr) } \\
\text { Urinalysis } \\
\text { Chest radiographs }\end{array}$ & $\begin{array}{l}\text { Yes } \\
48 \\
\text { Haematuria } \\
\text { Nodule }\end{array}$ & $\begin{array}{l}\text { Yes } \\
28 \\
\text { Normal } \\
\text { Subglottic } \\
\text { stenosis }\end{array}$ & $\begin{array}{l}\text { Yes } \\
63 \\
\text { Normal } \\
\text { Nodules }\end{array}$ & $\begin{array}{l}\text { Yes } \\
83 \\
\text { Haematuria } \\
\text { Nodules }\end{array}$ \\
\hline Biopsy & $\begin{array}{l}\text { Granulomatous } \\
\text { vasculitis }\end{array}$ & $\begin{array}{l}\text { Granulomatous } \\
\text { vasculitis }\end{array}$ & $\begin{array}{l}\text { Granulomatous } \\
\text { inflammation }\end{array}$ & $\begin{array}{l}\text { Granulomatous } \\
\text { vasculitis }\end{array}$ \\
\hline $\begin{array}{l}\text { cANCA } \\
\text { CT (head) } \\
\text { Neurological } \\
\text { findings }\end{array}$ & $\begin{array}{l}\text { ND } \\
\text { Normal } \\
\text { Horner's; } \\
\text { MM }\end{array}$ & $\begin{array}{l}\text { Positive } \\
\text { Normal } \\
\text { Horner's }\end{array}$ & $\begin{array}{l}\text { ND } \\
\text { ND } \\
\text { Horner's; } \\
\text { CN }\end{array}$ & $\begin{array}{l}\text { ND } \\
\text { Normal } \\
\text { Horner's; } \\
\text { MM }\end{array}$ \\
\hline
\end{tabular}

cANCA, anti-neutrophil cytoplasmic antibody; CN, multiple cranial neuropathies; ESR, erythrocyte sedimentation rate (Westergren); MM, mononeuropathy multiplex; ND, not done. and undetermined causes in $24 \cdot 1 \%$. Other causes included multiple sclerosis, tuberculosis, chronic infective granuloma, and herpes zoster. In a more recent study of 100 consecutive hospitalised patients, Keane ${ }^{5}$ found that Horner's syndrome resulted from cerebrovascular events in about half of the patients. Rare causes of the syndrome in his series included porphyria, carotid-orbital ischaemia, compression by subdural haematoma, cysticercosis, and arteriovenous malformation in the posterior fossa. Vasculitis or granulomatous disease was not mentioned in either series. We describe four patients who had Horner's syndrome caused by Wegener's granulomatosis (table).

\section{Case reports}

\section{Case 1}

In May 1983 a 69 year old woman had bilateral maxillary sinus pain and bloody discharge from both nostrils. In July, fatigue and numbness developed in the left fifth finger. In September, numbness and paraesthesia progressed to involve the ulnar side of the left forearm and hand. In October, there was numbness and weakness in the right foot and, subsequently, in the left foot.

In November, results of a general physical examination were normal, except for thick crusts and friable nasal mucosa on the nasal septum and right foot drop. The right pupil was miotic (2 $\mathrm{mm}$ in diameter on the right compared with $4 \mathrm{~mm}$ on the left), but there was no ptosis or ophthalmoplegia. Cranial nerve function was intact. There was severe weakness in the muscles innervated by the right peroneal nerve, moderate weakness in those innervated by the left ulnar nerve, and minimal weakness in those innervated by the left peroneal nerve. Minimal sensory deficit was observed in the distribution of the right peroneal nerve. Laboratory findings included ESR of $48 \mathrm{~mm} / \mathrm{hr}$ (Westergren), microscopic haematuria with erythrocyte casts on urinalysis, and normal chest radiographs. Nasal biopsy revealed findings consistent with Wegener's granulomatosis. Treatment with trimethoprim-sulfamethoxazole was followed by considerable improvement in the patient's condition.

There was no exacerbation until September 1987, when polyarthralgia, general malaise, and paraesthesia on the ulnar side of the right forearm developed. Examination revealed Horner's syndrome on the right. The right pupil was $2 \mathrm{~mm}$ in diam- 
eter and the left pupil $4 \mathrm{~mm}$. The right eye lid was moderately ptotic. Anhidrosis of the face was not present, and there was no ophthalmoplegia. Both pupils reacted to light promptly and on convergence. Cranial nerve function was intact. There was moderate weakness bilaterally of muscles innervated by the ulnar nerve and mild weakness of those innervated by the peroneal nerve. Chest radiographs showed a new $3 \mathrm{~cm}$ nodular infiltrate. Results of CT of the head with contrast medium were negative. Repeat nasal biopsy again revealed findings consistent with Wegener's granulomatosis. Treatment with prednisone $(60 \mathrm{mg} /$ day) was followed by considerable relief from the symptoms, including ptosis, and clearing of the pulmonary nodule. She died of carcinoma of the pancreas in 1990. No necropsy was performed.

\section{Case 2}

In 1983, a 23 year old woman with recurrent plugging of both ears was given the diagnosis of bilateral serous otitis media. In 1984, right facial nerve palsy and left Horner's syndrome developed and responded to a brief course of treatment with prednisone. In February 1987, she had progressive shortness of breath caused by subglottic stenosis. Prednisone ( 80 $\mathrm{mg} /$ day) was started and provided moderate relief from the dyspnoea.

In July 1987, she came to the Mayo Clinic for evaluation. On examination, Horner's syndrome was evident on the left side. The left eyelid was ptotic. The left pupil measured $3 \mathrm{~mm}$ and the right pupil $5 \mathrm{~mm}$. Both pupils reacted promptly to light. The ciliospinal response was prompt on the right but absent on the left. Administration of $1 \%$ hydroxyamphetamine produced minimal dilatation of the left pupil. There was no ophthalmoplegia or anhidrosis on the face. Cranial nerve function was intact. There was no weakness or sensory deficit. Laboratory findings were normal.

In August 1988, nasal crusting with occasional bloody discharges developed, and she returned to the Mayo Clinic. Horner's syndrome was not present. Nasal biopsy revealed findings consistent with Wegener's granulomatosis. The anti-neutrophil cytoplasmic antibody (cANCA) was positive in a dilution of $1: 8$. The diagnosis of localised Wegener's granulomatosis was made, and treatment with cyclophosphamide was started. As of October 1991, treatment with prednisone and cyclophosphamide was still effective.

Case 3

In March 1974 a 13 year old girl had an acute onset of severe throbbing headache. Sudden loss of hearing developed bilaterally and the diagnosis of serous otitis media was made. In May, she was noted to have anisocoria. A few days later, she experienced voice changes and difficulty swallowing. Fluids started to regurgitate through her nose and a left facial palsy developed.

In July, she came to the Mayo Clinic for evaluation. Examination revealed nasal voice, facial weakness, decreased taste, weakness of the tongue, vocal cord paralysis, weakness of soft palate, decreased gag reflex on the left, and bilateral hearing loss. The left eyelid was ptotic. The left pupil measured $3 \mathrm{~mm}$ and the right pupil $4 \mathrm{~mm}$. Both pupils reacted promptly to light. There was no ophthalmoplegia. The parotid gland on the left was markedly enlarged. ESR was $63 \mathrm{~mm} / \mathrm{hr}$. Biopsy of the parotid gland showed necrotising granulomatous inflammation but was indeterminate. The patient received antibiotics, with moderate improvement in her neurological status. One month later, Horner's syndrome was absent.

In September, she complained of diplopia and returned to the Mayo Clinic. Examination revealed left $\mathrm{CN} 6$ palsy, bilateral papilloedema, and mild residual $C N 7$ palsy. Cerebrospinal fluid examination revealed 8 lymphocytes $/ \mu \mathrm{L}$, protein of 16 $\mathrm{mg} / \mathrm{dL}$, and glucose of $68 \mathrm{mg} / \mathrm{dL}$. Prednisone therapy $(20 \mathrm{mg} /$ day) was started empirically, with complete resolution of her symptoms and cranial neuropathies.

In 1978 she had nasal septal ulceration with mucosal crusting, and the diagnosis of Wegener's granulomatosis was considered. The biopsy specimen of the parotid gland was reviewed and reinterpreted as necrotising granulomatous inflammation, with giant cells involving parotid gland and lymph nodes consistent with Wegener's granulomatosis. Trimethoprim-sulfamethoxazole was added to the treatment, and the response was good.

\section{Case 4}

In April 1984 a 71 year old man with fever and cough was found to have pulmonary infiltrates, which responded poorly to treatment with antibiotics. He then experienced severe headache and weight loss and was admitted to hospital. ESR was $83 \mathrm{~mm} / \mathrm{hr}$. Temporal artery biopsy was performed but did not reveal vasculitis. In December he had nasal congestion.

In January 1985 he came to the Mayo Clinic for further evaluation. His temperature was $38^{\circ} \mathrm{C}$. There was impressive crusting in both nostrils, with erosion of the underlying mucosa. Neurological examination showed Horner's syndrome on the right. The right pupil measured $2 \mathrm{~mm}$ and the left pupil $4 \mathrm{~mm}$. Ptosis was evident on the right. There was no ophthalmoplegia. Cranial nerve function was otherwise intact. There was moderate weakness of the muscles innervated by the right ulnar nerve, minimal weakness in those innervated by the right radial nerve, and minimal sensory deficit on the ulnar side of the right hand. Shortly after admission, paraesthesiae of the right foot developed. Electromyographical findings were consistent with asymmetrical peripheral neuropathy. Nasal biopsy revealed massive inflammatory infiltrates with foci of necrosis and granulomatous reaction and minimal vasculitis consistent with Wegener's granulomatosis. Cyclophosphamide therapy was initiated, and the patient was lost to follow up. 


\section{Discussion}

All four patients satisfied the diagnostic criteria for Wegener's granulomatosis ${ }^{6}$ and had Horner's syndrome characterised by miosis and ptosis. Horner's syndrome in these patients is most likely due to Wegener's granulomatosis, because the syndrome occurred at the time of the active stage of Wegener's granulomatosis and resolved with treatment.

Wegener's granulomatosis is characterised clinically by involvement of the nasopharynx, lung, and kidney, and pathologically by small vessel vasculitis with granulomatous inflammation. ${ }^{67}$ The most common neurological complications are mononeuropathy multiplex and cranial neuropathy. ${ }^{8}$ The ocular structures are affected in $30 \%$ to $60 \%$ of patients; ${ }^{9-11}$ three main categories are orbital disease, scleritis, and complications from vasculitis. $^{10}$ However, to our knowledge, Horner's syndrome has not been described in association with Wegener's granulomatosis. The possible pathophysiology of Horner's syndrome in these patients is either vasculitic involvement or granulomatous involvement of the oculosympathetic pathway between the hypothalamus and the orbit.

Localisation of the lesion in our patients is difficult because CT of the head, which was performed in three of the four patients, did not provide any clue and no necropsies were performed. However, infarction in the hypothalamus or brainstem is unlikely because Horner's syndrome resolved with treatment for Wegener's granulomatosis. Also, there were no other neurological symptoms suggestive of brainstem infarction. In patients 1 and 4, the vasculitic involvement of the vasa nervorum may have been the cause, because Horner's syndrome was concomitant with mononeuropathy multiplex, which is known to be due to systemic small vessel vasculitis. ${ }^{912}$ In patient 2 , pharmacological testing suggested a lesion of the postganglionic nerve. Because the disease was limited to the upper respiratory tract and there was a soft tissue mass in the nasal cavity, direct granulomatous invasion in the cavernous sinus region is most likely.9 The unilateral multiple cranial neuropathies and granulomatous involvement of the parotid gland in patient 3 suggest a direct or distant granulomatous lesion involving the postganglionic nerve fibres.

Wegener's granulomatosis can cause Horner's syndrome. Further studies with MRI and pharmacological testing and confirmation by necropsy findings are needed to define the cause of Horner's syndrome in Wegener's granulomatosis.

We thank Dr Paul W Brazis for his critical review of this manuscript.

1 Wilkins RH, Brody IA. Horner's syndrome. Arch Neurol 1968;19:540-2.

2 Miller NR. Walsh and Hoyt's clinical neuro-ophthalmology, 4th ed, vol 2. Baltimore: Williams and Wilkins, 1985:500-11.

3 Horner F. Ueber eine Form von Ptosis. Klin Monatsbl Augenheilkd 1869;7:193-8.

4 Giles CL, Henderson JW. Horner's syndrome: an analysis of 216 cases. Am $\mathcal{F}$ Ophthalmol 1958;46:289-96.

5 Keane JR. Oculosympathetic paresis: analysis of 100 hospitalized patients. Arch Neurol 1979;36:13-5.

6 Leavitt RY, Fauci AS, Bloch DA, et al. The American College of Rheumatology 1990 criteria for the classification of Wegener's granulomatosis. Arthritis Rheum 1990;33:1101-7.

7 Fauci AS, Haynes BF, Katz P, Wolff SM. Wegener's granulomatosis: prospective clinical and therapeutic experience with 85 patients for 21 years. Ann Intern Med 1983;98:76-85.

8 Nishino H, Rubino FA, DeRemee RA, Swanson JW, Parisi JE. Neurological involvement in Wegener's granulomatosis: an analysis of 324 consecutive patients a the Mayo Clinic. Ann Neurol 1993;33:4-9.

9 Drachman DA. Neurological complications of Wegener's granulomatosis. Arch Neurol 1963;8:145-55.

10 Miller NR. Walsh and Hoyt's clinical neuro-ophthalmology, 4th ed, vol 4. Baltimore: Williams and Wilkins, 1991:2575-729.

11 Bullen CL, Liesegang TJ, McDonald TJ, DeRemee RA Ocular complications of Wegener's granulomatosis. Ophthalmology 1983;90:279-90.

12 Stern GM, Hoffbrand AV, Urich $H$. The peripheral nerves and skeletal muscles in Wegener's granulomatosis: a clinico-pathological study of four cases. Brain 1965;88:151-64. 